Intersections. EEJSP

$1(1): 3-17$.

DDI: http://dx.doi.org/110.17356/iejejp.vili.80 http://intersections.tk.mta.hu

\title{
Mainstreaming the Extreme: Intersecting Challenges from the Far Right in Europe
}

\author{
* [feischmidt.margit@tk.mta.hu] (Centre for Social Sciences, Hungarian \\ Academy of Sciences, Hungary); [hervik@cgs.aau.dk] (Aalborg \\ University, Denmark)
}

This is the first issue of the new journal Intersections. East European Journal of Society and Politics (IEEJSP). As our point of departure, we take a timely subject for European societies: the far-right phenomenon as related to mainstream politics and discourse. Instead of relying exclusively on views of radical developments prevalent in the field of politics, our aim was to bring together insights from sociology, social anthropology, political science and media studies, as well as from discourse and network analysis, and integrate them into a comparative and interdisciplinary study of the phenomenon. As far as the investigated topics are concerned, special attention has been paid to the interplay of media and politics, the discursive aspects of politics, and the role of cultural commodification beyond ideologies on the supply side as well as recent developments explaining increasing interest on the demand side.

Most of the contributions are empirical case studies, the variety and diverse methodology of which is one virtue of our collection, but comparative and theoretical papers also contribute to the understanding of the global socio-political processes which are the framework of the mainstreaming effect ${ }^{1}$. But before presenting the articles of this issue, as introductory essays usually do, we would like to expand our own position on the topic. We begin by highlighting the significance of the discursive criminalization of migrants and minorities by Europe's far-right politics and media, as also adopted by many actors in mainstream media and politics. Presented as collective threats, the racialized "others" legitimize another set of discourses intended to reassert or re-sanctify native communities, especially the homogeneous perception of nation based on ethnicity and cultural values. This is what we claim in the second part of our essay, and we support this with predominantly Danish and Hungarian examples. Finally we conclude by claiming that neo-nationalism and neo-racism are the main engines of the process that we call 'mainstreaming the extreme'. Our statements lean

\footnotetext{
${ }^{1}$ The theme was covered at two conference panels organized by the editors ('Cultural strategies and social conditions of neo-nationalism in Europe' panel at the biannual conference of the European Association of Social Anthropologists, 2014, Tallinn, and the panel 'Neo-nationalism and the Youths' Radical Responses to Economic and Political Crises in Central and Eastern Europe' at the conference of the Association for Studies of Nationalities in Budapest, 2014) and was also motivated by a comparative workshop ('Far-right extremism in crisis-ridden Greece and beyond', organized by St Antony's College, University of Oxford, in June 2014). Nevertheless, most of the studies we publish here were submitted in response to our call for papers, and all underwent a standard journal peer review procedure.
} 
primarily on a discursive approach, one that is also employed by most of the studies we publish here ${ }^{2}$.

\section{Raising the level of the threat in media and politics}

The far right, as portrayed in today's academia, is an unparalleled, extreme and unforeseen deviancy of European societies. Its extreme nature is overstated which means that the representation of the far right has focused on uncommon, extreme forms of politics, with a special emphasis on the processes of radicalization into violent activism and terrorism (Bjørgo, 1997: 3).

In contrast, we claim here that the radical distinction and perceived difference between extreme and mainstream forms of politics has been exaggerated, and has therefore hindered analysts in observing the various and close relations between the two. But before raising the question of what has actually been disregarded, and what mainstreaming of the extreme implies exactly, we would like to look behind this bias and ask how this focus on the extreme and the exceptional has developed.

There is a consensus in media studies and political science that politics has to a large extent become saturated by the news and tabloid media. Ellinas (2009) highlights the role of media communication and appropriation in the recent success of European far-right parties, emphasizing more specifically how politics has become the dumping of simplistic slogans and gripping events easily accessible to the broader public. Furthermore, the disproportionate success of some of these parties, Ellinas claims, can be explained by the excessive exposure they receive in the media. As our previous investigations (Feischmidt et al., 2014, Hervik, 2008, 2011) have revealed, the relationship also works the other way around: certain media institutions have become successful in the media business precisely because they have found and presented far-right issues in an attractive and popular way.

The relationship between media and politics can be seen as part of a larger process, which some experts call the mediatization of society: a process whereby institutions, companies and individuals no longer operate independently of the news media, its logic and its experts. Thus, the understanding and the analysis of the news media or politics can only be understood as a single integral process (Hjarvard, 2008; Strömbeck, 2008). This has been particularly clear in the conduct of war, most notably since the Vietnam War, where the myth of winning the media war was born as a necessary condition for winning the war itself. In modern wars, the relationship between cause and effect has effectively become blurred (Hoskins and O'Loughlin 2010), as reflected in news media coverage.

Similarly, the rise of the far right in recent years would not have been possible without massive media support. Examples include the Austrian tabloid New Kronen Zeitung and its relationship to Freedom Party of Austria (Wodak and Pelinka, 2002), and the Danish tabloid paper Ekstra Bladet's three-month 'The Foreigners' campaign

\footnotetext{
${ }^{2}$ We are convinced that the sociological investigation of the structurally increasingly diverse categories of far-right supporters is important, and in this regard we think that the research direction of Don Kalb and his co-authors (cf. Kalb - Halmai 2011) is worth following. This is not fully implemented in our special issue and its introductory essay, however.
} 
and the establishment of the Danish People's Party in the spring of 1997. The invention by the highly intense radical online media world in Hungary of "gypsy crime" contributed in a similar way to the rise of the country's far-right Jobbik party. Moreover, the dual platform of far-right media and politics was supported by a growing media enterprise, with different actors moving back and forth between extreme and mainstream politics.

Ekstra Bladet's campaign against immigration was introduced as a call for a referendum on whether Denmark should become a multi-ethnic society. The editor argued that Danes had never been asked whether they accepted the immigration of foreigners. To meet the demand for a free political debate, Ekstra Bladet made this campaign appear to serve a crucial democratic function. The transformation of Denmark "from a peaceful society to a multi-ethnic one" is repeated again and again in the paper as a crime committed by politicians against the Danish people.

Ekstra Bladet placed itself squarely on the side of the ordinary and straightforward public with an aggressive, even vulgar, slogan: "daring where others don't". It might be, the editor argued, that "most politicians do not see any problems, but still there is a contract between voters and those who are supposed to rule us". But the rule is enacted without including the people. This populist stance and the idea of a referendum are two of the areas that blur the relationship between news media and political party. Others include the dominance of the Danish People's Party's sympathizers during the campaign: journalists interviewed authors of letters to the editor for full articles, who mostly turned out to be sympathizers of the Danish People's Party, while authors of letters to the editor would automatically receive letters of invitation to join the Danish People's Party. Finally, a key story in the campaign was a story about a Somali immigrant, Ali, his wife, ex-wife and children. These individuals were lumped together and presented as if Ali had received an enormous sum of social welfare payment as a single person. The story was invented by a journalist who, shortly after the campaign, wrote a manifesto-type book for the Danish People's Party and became the party's candidate for the European Parliament. New terms that emerged from Dahlerup's story became artefacts of the dominant neonationalist discourse: "Ali-loft", for example, a reference to the alleged need for legislating a limit ('loft' literally means 'ceiling' in Danish) to how much social welfare benefits foreigners could receive .

The broader tendencies of the symbiotic campaign can best be described as basic populism: against the élite, for the people, and against foreigners. In the wake of this successful campaign, polls showed that Danes experienced a drastic increase in fear of the presence of new foreign cultures and visibly different minorities (Hervik 2011), and of course expressed a new demand for authoritarian rule to be strengthened.

The news media discourse on "gypsy crime" in Hungary presents a similar situation. The introduction of the term "gypsy crime" for a new journalistic genre generated unprecedented success for, and proliferation of, the far-right (mainly online) media. The most popular far-right portal, kuruc.info, launched a special section on "gypsy crime", updated several times a day, almost exclusively listing Roma (always called "gypsy") suspects in connection with crime reports. Secondly, "gypsy crime" very soon became the clarion call for rising far-right party Jobbik and for even more 
extreme far-right movements and paramilitary organizations in Hungary. Moreover, as an in-depth description of the discourse on "gypsy crime" has shown, it is not only that with the notion of "gypsy crime" an openly racist language was introduced in Hungary, but that the term has become the symbol of "telling the truth", of breaking taboos in politics and public discourse. Of all incidents eliciting the expression "gypsy crime", the greatest amount of media coverage was generated by the "Olaszliszka lynching" incident and the establishment of the Hungarian Guard, a far-right paramilitary movement (Juhász, 2010).

The incident took place on 15 October 2006 in a village in the eastern part of Hungary. A passing car nearly hit a local Roma girl who had been walking on the street. When the driver, a teacher from a nearby town, stopped to see if the girl was all right, members of the girl's family and other Roma individuals who had witnessed the accident, wrongly believing that the girl had been severely wounded, beat the driver to death. The brutal scene, witnessed by the driver's two children, became known as the "Olaszliszka lynching” and was quickly turned into a metaphor for "gypsy crime". The 'Goy Riders', an organization claiming "to defend Hungarian national and Christian ideas and values", labelled the teacher a martyr and erected a monument in his memory at the site of the murder. The monument has since become a "place of pilgrimage" for members of far-right organizations claiming to fight "gypsy crime" in the country.

The second important event was the foundation of the Hungarian Guard in June 2007 (less than a year after the Olaszliszka tragedy). According to its statutes, the new paramilitary organization seeks to play a role in "the strengthening of national self-defence". It is under this pretext that members of the organization, wearing a uniform reminiscent of the Arrow Cross, the Hungarian Nazi party in the 1940s, marched through a number of villages inhabited by Roma, demanding the prosecution of "gypsy criminals" together with the restoration of public order and security in the countryside. Although the Hungarian Guard was not directly responsible for the so-called "Roma murders" that shook the country in 2008-2009, the four men charged with the nine attacks committed against innocent Roma, which claimed six lives were, according to the state prosecution's charges, in contact with farright groups. It is also worth noting that the scene of the most infamous attack of the "death brigade" was the village where the Guard first marched: Tatárszentgyörgy, where a 28-year-old father and his five-year-old-son were shot and killed while attempting to escape from their house (Feischmidt et al., 2013).

Although they play a key role, it is not only far-right organizations that criminalize the Roma and create an atmosphere prone to violence. Online news portals usually report smaller conflicts that would otherwise go unnoticed, with blogs specializing in "gypsy crime". Mainstream media and politicians pick up accounts from the new media associated with the far right, partly because they are often the only ones to report on an event, and partly because they fabricate and circulate interpretative frameworks that are easy to apply to mainstream media contexts as well. The same transfer strategy legitimized by taboo-breaking was applied in the case of some other topics (like the political and media discourses on penal populism in Hungary; see Boda et al., 2015). 
Analysing two of the above criminal cases (one where the victim was a nonRoma Hungarian and the perpetrator was a Roma person, and another where the perpetrator was a non-Roma Hungarian citizen and follower of one of the far-right paramilitary organizations), Vidra and Fox come to the conclusion that far-right media and politics have managed to set the agenda together by thematizing the Roma and by introducing the term "gypsy crime". Moreover, they claim, the far right's racism has become accepted into the mainstream, which has embraced the radical right's propositions and turned them into a "digestible" rhetoric, while breaking the taboos of anti-racism (Vidra - Fox, 2014: 52).

There are two further points to be made in the light of the Danish and the Hungarian cases that support our first general claim that the focus on the extreme plays on media coverage of violent acts. First, acts committed by fanatic followers of a far-right ideology against members of minorities and other perceived enemies; second, violent acts committed by members of minorities against members of the majority. Even more importantly, the far-right media plays an instigating and defining role in the narrative framework of both. The 'politics of fear', characteristic, as Ruth Wodak and her co-authors argue, of far-right discourse, depends on performative strategies, which claim victimhood through such dramatized and exaggerated media events (Wodak et al., 2013; Glózer, 2014).

\section{Restoring a nation's pride by blaming others}

Media coverage mentions the minority actors involved as well as the reasons for their acts. Articles tend to define non-nationals in cultural and moral terms, while the relation of minority actors to the nation is set up as a hierarchical difference associated with incompatibility. New racism first of all means the recovery of this hierarchical view, as produced by discriminatory and exclusionary language that seeks to justify and naturalize difference. As some new publications have revealed (Wodak KhosraviNik, 2013), in recent years racism has operated in more pervasive and diffuse forms, but its basic principles remain unaltered. The notion of an imagined community of cultural homogeneity implies that some people are included and others excluded, and that it is those who have this notion in common who decide on these matters. Those who subscribe to the notion claim that they have some "natural" right to the territory, that they have particular origins, often with certain racial features in common, and that they are part of a certain horizontal comradeship. Since the inclusion/exclusion dichotomy tends to fall precisely along "cultural" and/or "racial" lines, we can claim that neo-nationalism and neo-racism are two sides of the same phenomenon (Hervik, 2011).

One of the core issues of neo-racism is the adherence to the idea of incompatibility of non-Western or non-European "cultures" (Hervik, 2012); to the idea that living among one's own kind is natural, and that the inclination and right to defend your culture and territory is instinctive (Barker, 1981); to the ethno-theory of xenophobia as a natural and therefore justifiable reaction to the unwanted presence of annoyingly different migrants; to the denial of racism; and to the coding of race in terms of "difference", "culture" and "ethnicity". These different criteria are present in 
the far right's anti-migration and neo-nationalist scheme, yet each of them includes (pseudo-)denials of racism and other processes that in themselves constitute efforts at mainstreaming.

The claims of far-right actors for essential differences that the culturally inferior aliens represent in immigrant societies is supported by collective emotion, in particular by any collective threat. Analysing the case of Muhammad cartoons in Denmark and Sweden, Stig Arne Nohrsted (2013) goes further, claiming that mediated speculation regarding fears and dangers has created a culture of fear which acts as a breeding ground for new right-wing populism. Other researchers have revealed a close relationship between a high level of anti-migrant or anti-minority attitudes and the acceptance of new racist discourses (Lubbers et al., 2002), warranting the claim that these attitudes are the key to understand where and why far-right parties have emerged and established themselves successfully. As regards Hungary, home to the post-communist world's most successful far-right party (Jobbik), researchers have pointed out that anti-gypsyism was the main cause of Jobbik's breakthrough in 2009 (Bíró-Nagy - Róna, 2013) and that a greater proportion of Jobbik's sympathizers hold anti-gypsy attitudes than is the case for competing right- or left-wing parties. The general level of xenophobia in Hungary is also very high in comparison to other European countries (Krekó et al., 2011).

Hervik has found an increasing level of xenophobia amongst Danish youth. As one of his interviewees directly formulated, "It has become more acceptable today to say immigrants are a nuisance and should simply be sent home. This has become more acceptable" (Anne, student, 23 years). Similarly, Feischmidt has also found a high level of acceptance of racist discourse amongst Hungarian youth. The prevalent attitude of rejection vis-à-vis members of the Roma minority (which, in terms of its objective forms of expression, ranges from avoidance to calls for ethnic cleansing) was legitimized in two ways by the members of the focus groups she conducted: by reference to statistics or to (a small number of) tragic events that are widely circulated in the mainstream media, and by reference to criminal acts - typically theft, robbery or bodily harm - perpetrated by Roma individuals against the speaker or members of their family. Most of the participants used these sources of legitimization simultaneously, blurring allusions to "well-known" facts or events with personal stories used to buttress generalized statements. If this combination of mediatized criminal acts (such as the lynching of a teacher in front of his children in 2006 or the murder of a handball player in 2009) and personal complaints is explosive, it is because they mutually reinforce each other, generating a climate of fear and paranoia as upheld by the fantasy image of "gypsy crime" (Feischmidt 2014a).

Far-right rhetoric that reproduces racist images and arguments has not only spread in our societies because of their public resonance based on pre-existing prejudices - it has also been able to do so because serious political and media actors have failed to denounce these new forms of racism. In the Hungarian case, as Vidra and Fox argue, this is a result of the mainstream political elite either condoning or adopting this far-right rhetoric for fear of losing votes from the large segment of society that holds racist views and anti-Roma attitudes (Vidra and Fox, 2014).

As part of his view on the clash of civilizations, Samuel Huntington, one of the world's most influential intellectuals, emphasized "the necessity to hate someone in 
order to know who you are”. His inspiration comes from German professor of law and political theorist Carl Schmitt, who wrote this key statement on his approach to the political friend (or foe) in the post-World War I period: "We don't know who we are, if we don't know our enemies”. Huntington evokes Dibdin's novel Dead Lagoon: "There can be no true friends without true enemies. Unless we hate what we are not, we cannot love what we are. These are the old truths we are painfully rediscovering after a century and more of sentimental cant. Those who deny them deny their family, their heritage, their culture, their birthright, their very selves! They will not lightly be forgiven." Statesmen and scholars cannot ignore the unfortunate poignancy in these old truths. For peoples seeking identity and reinventing ethnicity, enemies are essential, and the enmities that are potentially most dangerous occur across the fault lines between the world's major civilizations (Huntington, 1996: 21).

Only at first is the relationship between these actors a distant one. Nevertheless, as our earlier research revealed, there is an emerging network relationship and a sharing of core values by a cluster of radical right-wing anti-Islam writers amongst Danish and North American neo-conservatives. A group of Denmark's most notorious far-right figures wrote hundreds of news articles and more than a dozen books on what they saw as the dangers of Islam. These authors form a network of people who present the Danish Muhammad cartoon conflict as a manifestation of the clash of civilizations, where Islam and Islamists have to be met with zero-tolerance and confrontation (Hervik, 2008, 2011). According to this view, Muslim cultural identity is irreconcilable with Danish or Western culture, because, as neo-conservatives declare again and again, there can be no moral equivalency between Western democracy and other forms of rule. "Our system of government" is morally superior and it is our duty to spread this to the rest of the world, they claim. Politically, they add, your opponent should be treated as an enemy with antagonistic zero-tolerance, even with a view to injure, overthrow or confound this opponent, sometimes harmfully or deadly (Coll, 2004; Mann, 2004). Such values and practices imply that adherents will go further with their rhetoric than their opponents, and thereby always attract more of the news media's attention.

Mainstreaming the extreme starts with accepting intolerance, as Kouki and Vidra (2014) argue or with accepting racism, as we claim here. The shift of the radical right towards the mainstream takes place through the reconfiguration of public speech on immigrants (above all Muslims) in most parts of Europe and through discourse on the Roma in Central and Eastern Europe. As we argued above, this can happen not only because Islam and Roma have become key issues for the political mobilization of various right-wing parties, and not even because large parts of our societies are receptive (for certain structural reasons) to anti-minority mobilization, but also because the far-right discourse has some basic concepts and arguments in common with mainstream thinking. Besides these causes, there is the intricate yet crucial question of how exactly this shift of racist discursive blocks from the margins to the centre takes place, or rather how this can be explained in societies that claim to be rational, egalitarian and democratic.

Images and arguments of the extreme right are incorporated by discourses considered to be moderate by responding to the demand created by themselves to come forward with "real problems", consciously hidden by the established actors of 
the mainstream. Examining Dutch public debates on multiculturalism through the 1990s into the late 2000s, Prins and Saharso (2010) observe the emergence of what they call "new realism", which can also be seen in the case of the tabloid paper Ekstra Bladet's self-presentation. "New realism" is characterized by a special discursive position that presents the author as someone who speaks "frankly" about the "truths" that the dominant political correct discourse has covered up; the author sets himself up as a spokesperson of ordinary people, spelling out the negative consequences of the increasing number of immigrants and minorities, such as high rates of criminality and an unwillingness to adapt to the cultural norms of the majority (Vertovec and Wessendorf, 2010: 33).

The mediatized political narrative of multiculturalism in crisis creates and defuses a new set of arguments which emphasize the way cultural differences lead to communal separateness, and how this separateness deepens socio-economic standing, intensifies the breakdown of social relations, and provides an incubator for extremism and possible terrorism. Within this line of thinking, blaming multiculturalism also entails putting the blame on immigrant/ethnic minorities themselves. With some rhetorical sleight-of-hand, moreover, the political elite which promoted multiculturalism can also be blamed (Vertovec and Wessendorf, 2010: 12-13). However, the alleged backlash against multiculturalism is really just a means to expand the far-right to such an extent that it becomes large enough to take over the mainstream. The mechanism is to build strength by fighting an enemy. This building of strength through this enemy's denigration is thus more than merely a matter of neonationalist celebration and neo-racist exclusion; rather, as rightly observed by Gingrich and Banks (2006), this may not be an end itself, and instead functions as a smokescreen that serves to hide and shield socio-economic priorities (2006: 18).

\section{Neo-racism and neo-nationalism: engines of mainstreaming}

In conclusion, we would like to summarize certain aspects of the process which we call mainstreaming the extreme. Mainstreaming refers first and foremost to a process of accommodation between the democratic political system and the populist far right. Scholars analysing this relationship in a broader context have identified three typical strategies that established political parties employ towards the rising far right: delegitimizing it (due to its incompatibility with democratic values), isolating it (by excluding it from electoral or executive alliances and public discussions) and embracing it (Pelinka, 2013). The last of these gives a greater chance to control farright actors, and more opportunity to unveil their professional inadequacies once they are brought into the fold. The problem becomes more acute and insistent when a government coalition of the moderate right and the populist far-right comes to power.

This was the case in Austria in 2000, when, after a long political reconciliation followed by a mostly critical public debate, ÖVP accepted a coalition with FPÖ. When analysing the impact of this decision, scholars have mostly emphasized the losses for the far-right and the benefits for the conservatives in the short term. This is not true, though, from a long-term perspective (Swoboda and Wiersma, 2008; Wodak, 2013). The coalition fosters an accommodation not only in one direction, 
namely of the extreme-right to the democratic mainstream, but also in the other: the adaptation of mainstream political discourse to the issues and logic of the extreme right. Moreover, in order for this interaction to come about, there is no need for a formal coalition. The literature has repeatedly pointed to the same claim made by our special issue: that this act of neo-conservatism embracing the far right is inevitably followed by adapting itself to it.

At the level of political discourse - as proposed in this introductory essay - this means that while there is a move away from the overt neo-fascist discourse of the far right, this does not indicate a decline in discriminatory and exclusionary language, but merely that racism has come to take more pervasive and diffuse forms (Wodak, 2013). Furthermore, the focus of the discourse is rephrased: the nation, national identity and the national territory turn out to be the main values, and their protection the main political aim. This is true not only of the old far-right movements in Western Europe, but also for most of their East European counterparts.

There is at the same time a move of the mainstream towards a politics of national identity which promotes collective values along with value-based and identitybased politics. The logic of this discursive shift is well exemplified in the following quote from a speech by the neo-conservative Danish prime minister: "It is actually my opinion that setting the agenda in the debate of values changes society much more than those changes to the law. When I speak broadly about culture: it is the outcome of the culture war that decides Denmark's future. Not the economic policies. Not the technocratic changes of the judicial system. What is decisive is who has the good fortune to set the agenda in the debate on values" (Hervik, 2014).

The Hungarian example also unambiguously shows what embracing and adaptation might mean, and what their political and symbolic consequences might be. The far-right movements and organizations broke into the public sphere in the first decade of the $21^{\text {st }}$ century with two issues: the first, the Roma issue, was presented in detail above. The second concerns a controversial, both politically and emotionally loaded moment of historical memory: 1920, the Treaty of Trianon, when Hungary lost two-thirds of its former territory and one half of its former population. This not only had practical consequences but deeply affected Hungarians' self-perception: from being a nation that took pride in its imperial superiority to being just one of the small countries of the region. Yet neither this loss nor identification with past glory was emphasized in the last decades (unlike the mainstream revisionism of the inter-war period), and was instead more likely to be avoided. This is why the topic became so appealing and attractive when in around 2006 far-right organizations began organizing Trianon commemorations, followed by far-right entrepreneurs who in a very short time created a nationalist popular culture employing the revisionist message. This is where the governing moderate right, which also employs a nationalist rhetoric and is always looking for timely forms for its identity politics, could not be left out. It has embraced and adopted the Trianon symbol for the official politics of memory (Feischmidt, 2014b).

Similarly, the radical right Danish People's Party invested in historical events to increase contemporary moral arguments when it turned to a poignant referendum in 1920 on the future border of southern Denmark and northern Germany. One of the posters for the campaign before the referendum showed a Danish child telling her 
mother: "Mum! Vote Danish. Think of me”. The Danish People's Party republished the poster and adopted the "Vote Danish" slogan for the parliamentary election in $1990^{3}$.

Of course, this process is not unique to one country or two; the political ambiguity of and the concurrent attachment to the moderate and extreme right are inherent to neo-nationalism in Europe (Gingrich-Banks, 2006). Studies of political culture and of media and political discourse have attempted to investigate the political visions and social perceptions employed by far-right figures, as well as the ways they have become acceptable and even desirable for a considerable proportion of society. Scholars have identified the decisive role of the re-imagination of "traditional" communities as against individualism and transnational identities, and of "integralist" world-views as opposed to Enlightenment-based visions of society; they also point to the controversial application of the values of European modernity (such as emancipation and tolerance) against the non-European (mostly Muslim) 'Others' (Holmes 2009). These perceptions are usually embedded in neo-nationalist discourses on the "endangered" cultural and moral integrity of the nation, along with discursive reifications of "annoying" or "dangerous" aliens. Though domestic social conditions and the history of nationalist thought vary widely, neo-nationalisms, like farright politics, show numerous similarities in different parts of Europe. It is these similarities we aim to use our comparative and interdisciplinary approach to understand here.

\section{Intersecting challenges of the far right in Europe: this issue of IEEJSP}

The first paper in this issue describes the broader context of the mainstreaming of farright phenomena by applying a political theory approach and analysing liberalism and democracy (as two distinct dimensions of 'good governance') as well as their current and their unfolding alternatives. Iván Szelényi and Tamás Csillag review versions of illiberal democratic capitalism in post-communist European societies, with particular emphasis on Russia and Hungary. They point out the characteristics inherent to national ideologies, and they emphasize their relationship to neo-conservative politics and thinking beyond the two countries, for example in the US and the EU.

Three papers analyse the relationship between the rise of the far right and the effects of new racism on the discourse on immigrants. Sindre Bangtsad convincingly portrays how much the process of mainstreaming is facilitated by the racist discourses and structures of European societies, a perspective that has not previously enjoyed much attention. Not even in a country like Norway, which both domestic and foreign scholars seem to have thought had overcome racism. Contrary to such general assumptions, Bangstad contextualizes Norwegian neo-racism with reference to persistent fears about a lack of social and national cohesion arising from modern mass immigration and an increasingly multicultural Norwegian society.

\footnotetext{
${ }^{3}$ Dahl, K. T. (1997) Kristian Thulesen Dahls Nytårstale 1997 (Kristian Thulesen Dahl's New Year's Speech, 1997). http://www.danskfolkeparti.dk/Kristian_Thulesen_Dahls_Nytårstale_1997 Accessed: 24 $02-2015$
} 
Peter Hervik explores how xenophobia, more exactly islamophobia embeds negative images of emancipative movements (multiculturalism, feminism) and of leftist or liberal political alternatives in Northern Europe. He approaches the coexistence of these negative images as "Scandinavian Nexus" with its blurred relations and taken for granted assumptions in the Muhammad Cartoon Affair in Denmark, the media coverage of the terrorist attack in Norway 2011 and two more recent media events.

Giorgos Tsimouris investigates a country with completely different economic and political conditions, yet arrives at similar conclusions. He claims that the electoral success of the Greek far right is closely associated with its anti-immigrant discourse and with actions in Athens and other Greek cities. Tsimouris acknowledges the significance of Golden Dawn's attempt to provide protection to the Greek public after the state retreated to a large extent from welfare services. He nevertheless emphasizes the effects of mainstream anti-immigrant discourse and representation, which have further deteriorated, intensified and expanded during economic crisis. The 'immigrant other', as Tsimouris formulates it, came to the forefront of political debate as the dangerous and contaminating 'other' refabricating the popular 'deep structures' of nationalism and patriarchal relations.

Sik investigates social and historical factors determining the political culture of young Hungarians. Based on semi-structured interviews conducted in two Hungarian cities he argues that two typical forms of political culture (the 'hopeless' and the 'indifferent') characteristic for the younger generation create the opportunity for antidemocratic tendencies and the space in which these tendencies can evolve.

Two papers are based on empirical media investigations. Szabó and Bene have studied the relationship of radical-right media actors (and their networks) with the mainstream (the networks of the general media sphere) through media coverage of particular issues. They argue that the transfer of topics and their discursive framework is limited, and that the far-right media is isolated by the mainstream. Compared with the results of other research on the Hungarian media (Messing and Bernáth, 2012; Vidra and Fox, 2014; Juhász, 2010), the difference is evident, and can be explained by the selection of topics for investigation. While certain issues (like "gypsy crime") have indeed generated the mainstreaming process, others (e.g. the issue of the nuclear power station at Paks) tend to work against it.

The other media analysis is a classic investigation of media coverage of far-right actors. Kluknavska studied the ways Slovak far-right politician Marian Kotleba was presented in the media during the 2013 regional elections. She argues that the discourse on the far right was mainly framed in terms of it being a threat, which contributed greatly to the increase of its popularity.

Two further papers in this issue apply a gender perspective on the study of the far right, and reveal the relevance of the representation of women and LGBTIQ people in the process of mainstreaming. Anikó Félix analyses forms of female participation and the discourse which provides a framework for this in public debate. She demonstrates that, for the far right, the ideal woman is limited to her reproductive role, which has not only a biological but also a cultural aspect. The feminine version of "true Hungarianness" is more attractive for those who sympathize with the far right but who are as yet not devoted to it. Thus it appears to be an efficient medium in the mainstreaming process. 
Izidora Stakić analyses the representation of homosexuality and LGBTIQ people within the discourse of the Serbian far right, emphasizing the discursive construction of LGBTIQ minorities as a security threat. She argues that the narratives of Serbian far-right groups acquire legitimacy due to their coherence with the mainstream discourse on homosexuality and LGBTIQ rights. Moreover, through the securitization of sexual minorities in far-right discourse, Serbian national identity is being both reified and strengthened.

\section{References}

Barker, M. (1981) The New Racism. Conservatives and the Ideology of the Tribe. London: Junction Books.

Bíró-Nagy, A. and D. Róna (2013) Rational Radicalism: Jobbik's Road to the Hungarian Parliament. In Mesežnikov G, O. Gyárfášová and Z. Bútorová (eds.) Alternative Politics?: The Rise of New Political Parties in Central Europe. Bratislava: Institute for Public Affairs 149-183.

Bjørgo, T. (1997) Racist and Right-wing Violence in Scandinavia. Patterns, Perpetrators and Responses. Oslo: Tano Aschehoug.-

Boda, Zs., G. Szabó, A. Bartha, G. Medve-Bálint and Zs. Vidra (2015) Politically Driven: Mapping Political and Media Discourses of Penal Populism-The Hungarian Case. East European Politics and Societies. OnlineFirst published on December 4, 2014 as doi:10.1177/0888325414557026, 1-21.

Coll, S. (2004) Ghost Wars: The Secret History of the CIA, Afghanistan, and Bin Laden, from the Soviet Invasion to September 10, 2001. New York: Penguin Books.

Ellinas, A. A. (2009) Chaotic but Popular? Extreme-Right Organisation and Performance in the Age of Media Communication. Journal of Contemporary European Studies, 17 (2): 209-221.

Feischmidt, M. (2014a) Neonationalism and Far-right Support amongst Hungarian Youth. Paper presented at the Association for the Study of Nationalities (ASN) 'Nationalist Responses to Economic and Political Crises' Conference, 12-14 June 2014. Central European University, Budapest.

Feischmidt, M. (2014b) Populáris emlékezetpolitikák és az újnacionalizmus: a Trianon-kultusz társadalmi alapjai (Popular Policies of Memories and Neonationalism: Societal Foundations of the Trianon Cult). In Feischmidt, M. et al. Nemzet a mindennapokban: Az újnacionalizmus populáris kultúrája (Nation in Everyday Life: Popular Culture of Neo-nationalism). Budapest: L’ Harmattan. 5181.

Feischmidt, M., R. Glózer, Z. Ilyés, V.K. Kasznár and I. Zakariás (2014) Nemzet a mindennapokban: Az újnacionalizmus populáris kultúrája (Nation in Everyday Life: Popular Culture of Neo-nationalism). Budapest: L' Harmattan. 
Feischmidt, M., K. Szombati and P. Szuhay (2013) Collective Criminalization of Roma in Central and Eastern Europe: Social Causes, Circumstances, Consequences. In S. Body-Gendrot, M. Hough, K. Kerezsi, R. Lévy and S. Snacken (eds.) The Routledge Handbook of European Criminology. London: Routledge.

Gingrich, A. and M. Banks (2006) Neo-Nationalism in Europe and Beyond. Perspectives from Social Anthropology. New York: Berghahn Books.

Glózer, R. (2014) A nemzet helyreállítása a magyarországi nemzeti radikális mozgalom ellenségtematizáló diskurzusaiban (Restoringthe Nation in Discourses of National Radical Movements Thematizing Enemies). In: Feischmidt, M. et al. .Nemzet a mindennapokban: Az újnacionalizmus populáris kultúrája (Nation in Everyday Life: Popular Culture of Neo-nationalism), Budapest: L’Harmattan. 159208.

Hervik, P. (2008) Integration through Insult. In Eide, E., R. Kunelius and A. Phillips (eds.) Transnational Media Events. The Mohammed Cartoons and the Imagined Clash of Civilizations. Gothenburg: Nordicom. 213-234.

Hervik, P. (2011) The Annoying Difference. The Emergence of Danish Neonationalism, Neoracism, and Populism in the Post-1989 World. New York and Oxford: Berghahn Books.

Hervik, P. (2012) Ending Tolerance as a Solution to Incompatibility: The Danish 'Crisis of Multiculturalism'. European Journal of Cultural Studies, 15 (2): 211-225.

Hervik, P. (2014) Cultural War of Values: The Proliferation of Moral Identities in the Danish Public Sphere. In Tripathy, J. and S. Padmanabhan (eds.) Becoming Minority: How Discourses and Policies Produce Minorities in Europe and India, New Delhi: Sage. 154-173.

Hjarvard, S. (2008) The Mediatization of Society: A Theory of the Media as Agents of Social and Cultural Change. Nordicom Review, 29 (2): 105-134.

Holmes, D. R. (2009) Integral Europe: Fast-capitalism, Multiculturalism, Neofascism. Princeton, NJ: Princeton University Press.

Hoskins, A. and B. O’Loughlin (2010) War and Media: The Emergence of Diffused War. Cambridge UK: Polity Press.

Huntington, S. P. (1996) The Clash of Civilizations and the Remaking of World Order. New York: Simon \& Schuster.

Juhász, A. (2010) The appropriation of the Roma issue. MS.

Hara, K. and Zs. Vidra (2014) Introduction to the Special Issue: New Forms of Intolerance in European Political Life. Journal of Immigrant and Refugee Studies, 12 (4): 353-362.

Kalb, D. and G. Halmai (2011) (eds.) Headlines of Nation, Subtexts of Class. Working Class Populism and the Return of the Repressed in Neoliberal Europe. Oxford: Berghahn Books. 
Krekó, P., A. Juhász and Cs. Molnár (2011) A szélsőjobboldal iránti kereslet növekedése Magyarországon (The Rise of the Social Demand for Rightwing Extremism in Hungary). Politikatudományi Szemle, 22 (2): 53-79.

Lubbers, M., M. Gijsberts and P. Scheepers (2002) Extreme Right-wing Voting in Western Europe. European Journal of Political Research, 41 (3): 345-378.

Mann, J. (2004) Rise of the Vulcans: The History of Bush's War Cabinet. New York: Penguin Books.

Messing, V. and G. Bernáth (2012) “Szélre tolva”. Roma médiakép 2011 (Pushed aside. Roma in the Media 2011) Médiakutató http://www.mediakutato.hu/cikk/2012_01_tavasz/05_roma_mediakep

Nohrstedt, S. A. (2013) Mediatization as an Echo-Chamber for Xenophobia Discourses in the Threat Society: The Muhammad Cartoons in Denmark and Sweden. In Wodak, R., M. KhosraviNik and B. Mral (eds.). Rightwing Populism in Europe: Politics and Discourse. London: Bloomsbury Academic. 309-320.

Rydgren, J. (2007) The Sociology of the Radical Right. Annual Review of Sociology 33: $241-262$.

Pelinka, A. (2013) Right-Wing Populism: Concept and Typology. In Wodak, R., M. KhosraviNik and B. Mral (eds.). Rightwing Populism in Europe: Politics and Discourse. London: Bloomsbury Academic. 3-22.

Prins, B. and S. Saharso (2010) From Toleration to Repression: The Dutch Backlash against Multiculturalism. In Vertovec, S. and S. Wessendorf, (eds.) The Multiculturalism Backlash. European Discourses, Policies and Practices. Oxon: Routledge. 72-91.

Strömbeck, J. (2008) Four Phases of Mediatization: An Analysis of the Mediatization of Politics. International.Journal of Press/Politics, 13 (3): 228-246.

Swoboda, H. and J. M. Wiersma (2008) (eds.) Democracy, Populism and Minority Rights. PSE, Socialist Group in the European Parliament.

Vertovec, S. and S. Wessendorf (2010) (eds.) The Multicultural Backlash: European Discourses, Policies and Practices. London: Routledge.

Vidra, Zs. and J. Fox (2014) Mainstreaming of Racist Anti-Roma Discourses in the Media in Hungary. Journal of Immigrant and Refugee Studies, 12 (4): 437-455.

Wodak, R. (2013) Anything Goes. The Haiderization of Europe. In Wodak, R., M. KhosraviNik and B. Mral (eds.) Rightwing Populism in Europe: Politics and Discourse. London: Bloomsbury Academic. 23-38.

Wodak, R. and A. Pelinka (2002) From Waldheim to Haider - an Introduction. In Wodak, R. and A. Pelinka (eds.) The Haider Phenomenon. London: Transaction Publishers. vï-xxvï.

Wodak, R. and M. KhosraviNik (2013) Dynamics of Discourse and Politics in Rightwing Populism in Europe and Beyond: An Introduction. In: Wodak, R., M. 
Intersections. EAST EURopeanJournal of Society and Politics, 1 (1): 3-17.

FEISCHMIDT, M. AND P. HERVIK: MAINSTREAMING THE EXTREME

KhosraviNik and B. Mral (eds.) Rightwing Populism in Europe: Politics and Discourse. London: Bloomsbury Academic. xvii-xxviii.

Wodak, R., M. KhosraviNik and B. Mral (2013) (eds.) Rightwing Populism in Europe: Politics and Discourse. London: Bloomsbury Academic. 